\title{
A Hydrological Budget (2002-2008) for a Large Subtropical Wetland Ecosystem Indicates Marine Groundwater Discharge Accompanies Diminished Freshwater Flow
}

\author{
Amartya K. Saha • Christopher S. Moses • \\ René M. Price • Victor Engel • Thomas J. Smith III • \\ Gordon Anderson
}

Received: 26 October 2010 /Revised: 16 May 2011 / Accepted: 7 October 2011 /Published online: 9 December 2011

(C) Coastal and Estuarine Research Federation 2011

\begin{abstract}
Water budget parameters are estimated for Shark River Slough (SRS), the main drainage within Everglades National Park (ENP) from 2002 to 2008. Inputs to the water budget include surface water inflows and precipitation while outputs consist of evapotranspiration, discharge to the Gulf of Mexico and seepage losses due to municipal wellfield extraction. The daily change in volume of SRS is equated to the difference between input and outputs yielding a residual term consisting of component errors and net groundwater exchange. Results predict significant
\end{abstract}

A. K. Saha $(\bowtie) \cdot$ C. S. Moses $\cdot$ R. M. Price

Southeast Environmental Research Center,

Florida International University,

11200 SW 8th Street, Bldg., OE-148, Miami, FL 33199, USA

e-mail: asaha@bio.miami.edu

R. M. Price

Department of Earth and Environment,

Florida International University,

11200 SW 8th Street, PC-344, Miami, FL 33199, USA

V. Engel

South Florida Ecosystem Office,

Everglades National Park,

950 N. Krome Ave.,

Homestead, FL 33030, USA

\section{T. J. Smith III}

Southeast Ecological Science Center, U.S. Geological Survey, 600 Fourth Street South,

St. Petersburg, FL 33701, USA

G. Anderson

USGS-Southeast Ecology Science Center,

Everglades Field Station,

40001 SR 9336,

Homestead, FL 33034, USA net groundwater discharge to the SRS peaking in June and positively correlated with surface water salinity at the mangrove ecotone, lagging by 1 month. Precipitation, the largest input to the SRS, is offset by ET (the largest output); thereby highlighting the importance of increasing fresh water inflows into ENP for maintaining conditions in terrestrial, estuarine, and marine ecosystems of South Florida.

Keywords Hydrological budget . Everglades .

Evapotranspiration · Groundwater discharge $\cdot$ Salinity

\section{Introduction}

Water availability and flow are the principal determinants of structure and function in wetland ecosystems (Mitsch and Gosselink 1993), where the juxtaposition of seasonally varying water level and topography creates a mosaic of flooded and emergent areas. Natural wetlands all over the world have been degraded by human activities from drainage to pollution and wetland biodiversity continues to decrease (Butchart et al. 2010). Restoration of a large, heterogeneous wetland ecosystem requires knowledge of how the specific hydrologic regime interacts with the structure and function of the inherent plant and animal communities. A first step in understanding the ecohydrology of a large wetland would be to quantify the hydrological pathways leading into and out of the ecosystem, together with noting their seasonal and inter-annual variation (Carter 1986; Dadaser-Celik et al. 2006). Relating the inputs and outputs to changes in water level and water storage produces a water budget (Bedient et al. 2008). A water budget is necessary to predict how flow, residence 
time, and water level would respond to changes in the sources (LaBaugh 1986) that can arise from environmental change and water management. This information is critical in both natural and constructed hydrologically controlled ecosystems (German 2000; Lott and Hunt 2001) because water depth, frequency of flooding, and flow patterns govern groundwater recharge (Goes 1999), biogeochemical cycling, carbon sequestration and greenhouse gas emission (Mitsch et al. 2010), nutrient availability (Childers et al. 2006), species composition based on flood/drought tolerances, and the extent of aquatic habitat in the dry season to enumerate a few examples.

The calculation of water budgets for constructed wetlands and small natural wetlands (surface area $<400 \mathrm{~km}^{2}$ ) has been well documented in the literature (e.g., Koerselman 1989; Becht and Harper 2002; Zhang and Mitsch 2005, Favero et al. 2007, Rodriguez-Rodriguez et al. 2007) while larger wetland ecosystem water budget studies are not as numerous; examples include the Nigerian Hadejia-Nguru wetlands (Goes 1999), Okavango delta floodplain wetlands (Ramberg et al. 2006) and the Ortuluakar Marsh in Turkey (Dadaser-Celik et al. 2006). Large wetland ecosystems such as the Everglades and the Pantanal possess complexity in hydrological path- ways; for instance, evapotranspiration can vary spatially with vegetation type (Camacho et al. 1974; Rawson et al. 1977, Tardeau and Simonneau 1998) and seasonally with plant phenology. Groundwater-surface water interactions can vary across spatial scales and can be important in not only transporting water, but also chemicals and nutrients from one water reservoir to another (Sophocleous 2002). Landscape grid water budget models account for spatial heterogeneity in water inputs and outputs (e.g., Fitz et al. 2004) by estimating these for each grid cell and summing up to get a basin-wide estimate. However the possibilities of error propagation in finite element modeling approaches indicate that it would be beneficial to have an independent validation of the basinlevel water inputs and outputs. Here, we describe the development of a basin-level water budget for Shark River Slough (SRS), at around $1,700 \mathrm{~km}^{2}$ the main drainage in the Everglades National Park, as the backbone in understanding its eco-hydrology as well as to provide a means of validation for landscape spatial models.

The Everglades is a slowly flowing subtropical wetland ecosystem with the bulk of its discharge entering the Gulf of Mexico and Florida Bay (Fig. 1). Flow velocities vary seasonally from upto $2 \mathrm{~cm} / \mathrm{s}$ in the wet season to $<0.1 \mathrm{~cm} / \mathrm{s}$

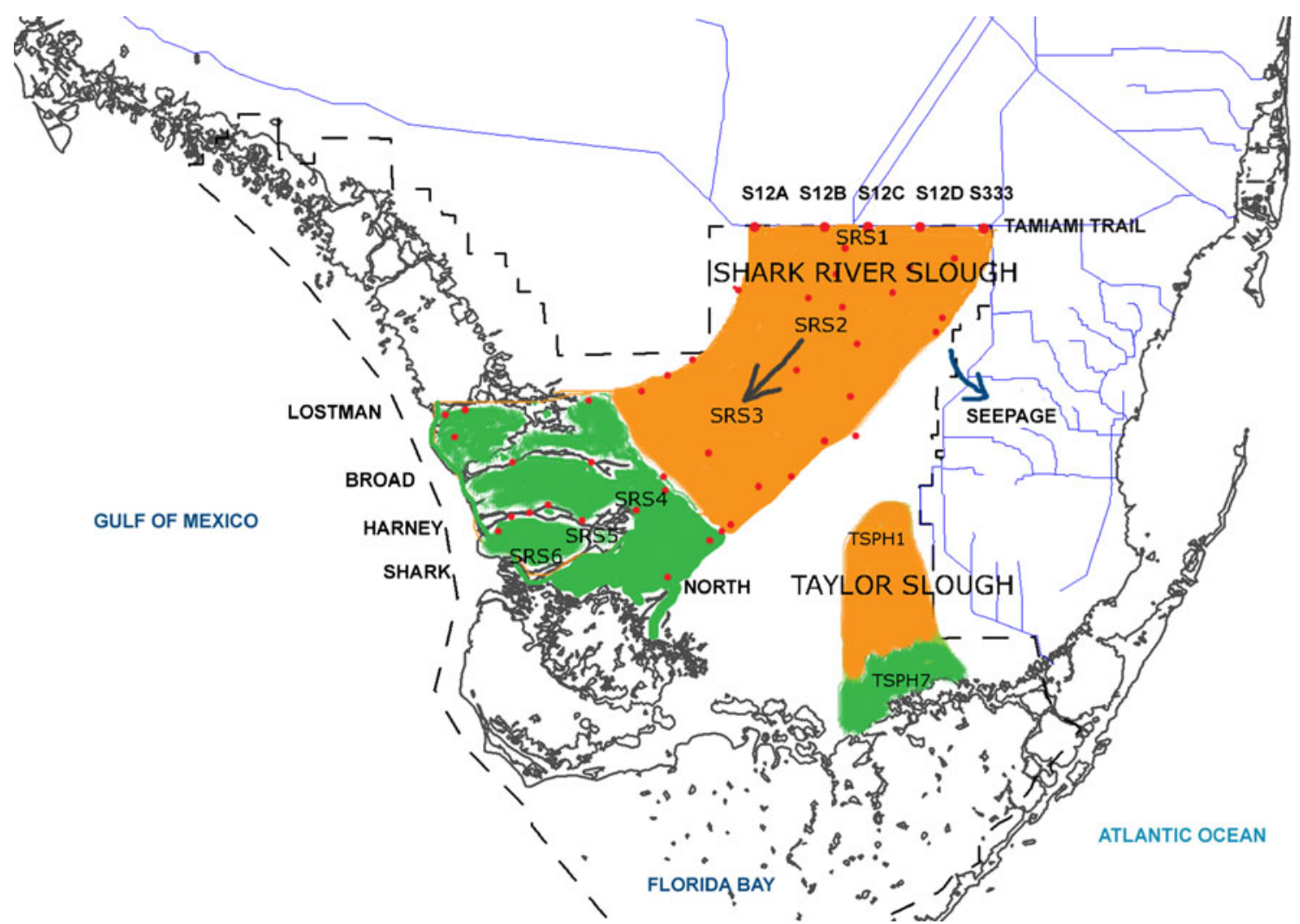

Fig. 1 Shark River Slough delineated in the Everglades National Park with locations of inflow structures (s12s and s333), major outflowing rivers, and FCE-LTER stations (SRS 1-6). The freshwater section is shown in orange while the estuarine section adjacent to the Gulf of
Mexico is shown in green. Red dots indicate sampling locations for water level. Arrow indicates direction of water flow. Also shown in the map is Taylor Slough along with two stations TSPH1 and TSPH7 where weather towers are located 
in the dry season (e.g., Riscassi and Schaffranek 2004). Large scale hydrological alterations in the northern Everglades through construction of canals and levees for floodcontrol, water storage and drainage in since the early twentieth century have compartmentalized the previously free-flowing system (Duever et al. 1986; Light and Dineen 1994). Water management upstream of Everglades National Park (ENP) has greatly reduced inflows, altered flow regimes and water depth in ENP, thereby severely impacting the Everglades ecosystem as well as that of downstream Florida Bay (Smith et al. 1989; Fourqurean 1999). In addition, the reduction in freshwater inflows along with ongoing sea level rise is responsible for the advancing seawater intrusion into the Everglades (Fitterman et al. 1999; Price et al. 2006; Saha et al. 2011) that is accompanied by landward encroachment of mangroves into the previously freshwater portions of the Everglades (e.g., Ross et al. 2001). The central issue in Everglades restoration is to restore surface water towards pre-drainage levels and flow rates in order to achieve the hydrological requirements for different native plant and animal communities. To mention a few examples, hardwood hammock plants occupy a narrow ecological niche bounded by susceptibility to both flooding and drought (Saha et al. 2009) as well as salinity (Olmsted and Loope 1984). Everglades freshwater fish communities regulate their population size based on seasonal expansion and shrinking of pools of water; thus droughts or water diversions/sudden releases adversely affect these communities (DeAngelis et al. 2010) leading to cascading effects throughout trophic levels in the entire ecosystem (Rehage and Trexler 2006).

Everglades National Park has two watersheds (Fig. 1) with distinct ecosystems that are only connected in very wet years: SRS that has tides from the Gulf of Mexico reaching $30 \mathrm{~km}$ inland and Taylor Slough that experiences very small tidal influence. Water budgets have been created for portions of the northern Everglades (Nungesser and Chimney 2006), Taylor Slough (Sutula et al. 2001), Florida Bay (Nuttle 1995), and for the entire Everglades ecosystem (Fitz et al. 2004) that includes the entire ENP as a single unit. As the major drainage of ENP, Shark River Slough requires its own water budget that will aid the calculation of water residence times and link the hydrological cycle with ecosystem processes of Shark Slough and the estuary. Hence we calculate a water budget for the SRS based on daily data available from 2002 to 2008. Inter-annual variability in annual rainfall together with an equally large variation in water releases to the park and discharges to the Gulf of Mexico (e.g., Donders et al. 2008) results in water budgets acquiring this wide range of inter-annual variability. Thus, a multiyear calculation of the SRS water budget provides a better representation of the natural range of water budget components. We also report water budgets at a monthly scale, to demonstrate seasonal changes in the inputs and outputs.
Given the range of woody and herbaceous plant communities with associated differences in transpiration, we estimate evapotranspiration using various models and modify a model to account for water limiting conditions. In addition, the budget estimates net groundwater discharge to the SRS that has been hypothesized to occur (Price et al. 2006) in the estuarine zone; hence we compare the groundwater discharge estimated by the budget with surface water salinity data at the mangrove-sawgrass ecotone that marks the dynamic boundary between halophytes and freshwater vegetation (Fig. 1).

\section{Methods}

Study Location The Shark River Slough is bounded by US Highway 41 to the north, by the Gulf of Mexico to the Southeast (Fig. 1), by the mid-pleistocene Miami Rock Ridge to the east and to the west by slightly elevated marl prairies; the difference in elevation is in the range of $\sim 1 \mathrm{~m}$ spread over $5-10-\mathrm{km}$ distance. The slough includes an estuarine zone extending about $30 \mathrm{~km}$ inland from the Gulf of Mexico that is dominated by mangroves, while the northern part has a ridge and slough landscape pattern, with floating and submerged aquatic macrophytes in the deepest sections (the sloughs), sawgrass marshes along the higher ground (the ridges) and tree islands. The areal extent of SRS used in this water budget was about $1,700 \mathrm{~km}^{2}$ encapsulating both the northern freshwater and the southern estuarine zones (Fig. 1). Soils in the slough are primarily peat (1 to $2 \mathrm{~m}$ depth) overlying permeable limestone bedrock which is the upper part of the unconfined Biscayne aquifer. With a seasonal subtropical climate, the region seldom experiences freezing temperatures. During the dry season (November to May), some parts of the SRS are dry. The slough has an average wet season (June to October) water depth of $1 \mathrm{~m}$ in the northern part increasing to about $3 \mathrm{~m}$ in the channels draining to the Gulf of Mexico.

Water Budget The water budget was computed as a water balance on a daily basis according to the following equation:

$$
\begin{aligned}
\Delta V= & \text { Rain }+ \text { Inflow }- \text { ET }- \text { Outflow }- \text { Seepage } \\
& \pm \text { Groundwater discharge } \pm \text { Error in all terms }
\end{aligned}
$$

where $\Delta V$ was daily change in water volume over the slough, rain was the spatially-averaged precipitation for 1 day over the slough, inflows were surface water deliveries into the ENP via control structures, evapotranspiration (ET) was evapotranspiration averaged over the slough, outflow represented the discharge from the slough into the Gulf of Mexico and seepage was the daily loss of water along the eastern boundary of ENP caused by water 
extraction outside the park. Estimating net groundwater exchange involves the largest amount of uncertainity (Sutula et al. 2001). All water budget terms were ultimately expressed in millimeters per day by normalizing the volume with the area of the SRS. The daily values were summed to yield monthly and annual values over the period 2002 through 2008.

Precipitation Daily rainfall data (2002 through 2008) were obtained from the Everglades Depth Network website (http:// sofia.usgs.gov/eden/nexrad.php)/. These data were radarderived estimates (Huebner 2008; Skinner et al. 2009) at 48 sites in the SRS that were calibrated against data from 81 rain gauges throughout South Florida for enhanced accuracy. Data from each station were summed to obtain monthly values that were then averaged spatially using the Thiessen polygon method (Thiessen 1911) to yield an average depth of precipitation across the slough in the units of cubic meters per month.

Inflows Surface water inflows to Shark Slough were largely through five main hydrological structures S12A, S12B, S12C, S12D, and S333 (Riscassi and Schaffranek 2004); the culverts receive their flow from S333. Flow data at these structures were obtained from the National Water Information System (NWIS; http://waterdata.usgs.gov/fl/nwis). Sheet flow into the slough from the west and the east was assumed to be negligible in comparison to the flow down the slough, as inferred from the orientation of tree islands along the main flow direction, and also seen from the preponderance of flow along the NE-SW direction (Riscassi and Schffranek 2004; Price et al., unpublished data). Daily average flow data in cubic feet per second were summed to obtain daily and monthly total values and converted to cubic meters per second. Errors in the inflow estimates were primarily related to instrument measurement precision and the scaling relationships used to calculate discharge from velocity measurements (Ruhl and Simpson 2005).

Discharge More than $90 \%$ of the discharge from the SRS was channelized through five major rivers: Shark, Lostman, Harney, Broad, and North (Levesque 2004) at the southwestern end of the slough (Fig. 1). Tidally filtered discharge data were obtained online from the NWIS and daily and monthly discharge amounts were calculated in a manner similar to inflows. The discharge data were reported on a 30-min basis, with positive and negative values indicating downstream and upstream flow (high tides entering channels), respectively. Data were summed over each 24-h period to calculate daily net discharge values. Error estimates in the discharges (Levesque 2004) together with those inherent in acoustic Doppler velocity flow measurement devices (Ruhl and Simpson 2005) suggest an error of $\pm 5 \%$.
Seepage Losses Water levels in the canals adjacent to ENP are kept low in order to prevent flooding of adjacent urban and agricultural lands. The low water levels in the canals along with municipal groundwater withdrawals in MiamiDade county east of ENP drives groundwater out of ENP via seepage under levee L-31. Seepage losses were estimated using regression equations (Nemeth et al. 2000) that relate the groundwater head differential across the levee L31 to seepage estimates calculated by MODBRANCH, a detailed reach-transmissivity flow model. Groundwater level data for 2002-2008 were available (http://waterdata.usgs.gov/fl/nwis) for pairs of wells, each pair on the western and eastern sides of the levee L31. Values obtained were in seepage loss/foot of levee per day, which was then multiplied by the length of the levee $(40 \mathrm{~km})$ to yield the total seepage loss/day.

\section{Evapotranspiration}

The absence of methods for the direct measurement of ET at spatial scales larger than individual trees necessitates indirect approaches towards estimating this important component of the water budget in wetland ecosystems. This study compared results from five widely used vapor transport models (Table 1) and the Bowen Ratio method. The combination Penman-Monteith (PM) model (Shuttleworth 1992) was then selected amongst these models to estimate ET for SRS, because this model incorporates some vegetation influences on ET (Leaf Area Index (LAI) and vegetation height), while the others account solely for meteorological factors. These other vapor transport models were FAO PM equation (Allen et al. 1998), Priestley-Taylor (Priestley and Taylor 1972), Abtew's simple radiation model (Abtew 1996), and the Modified Turc Model (Turc 1961). In addition, as mentioned, ET was also calculated from latent heat measurements at the eddy covariance flux tower (SRS6; Barr et al. 2010). Latent heat flux data $\left(\mathrm{W} / \mathrm{m}^{2}\right)$ were obtained for half-hourly periods from the eddy covariance tower at SRS6 (Barr et al. 2010). ET was then estimated as follows:

$\mathrm{ET}(\mathrm{g} / \mathrm{s})=($ latent heat flux/latent heat of vaporization $)$

The combination PM model was then adjusted for seasonal change in transpiration as follows:

$\mathrm{ET}=\frac{1}{\lambda}\left[\frac{\Delta A+\rho_{\mathrm{a}} c_{\rho} \frac{D}{r_{\mathrm{a}}}}{\Delta+\gamma\left(1+\frac{r_{\mathrm{s}}}{r_{\mathrm{a}}}\right)}\right] * 0.5(\operatorname{Sin}(\theta)+1)$.

The presence of foliage does not necessarily indicate active transpiration, as trees shut down stomata when facing water stress due to either soil moisture deficits that are close 
Table 1 Annual evapotranspiration (ET) estimates in mm/year obtained for Shark River Slough by five vapor transport models, the Bowen Ratio method and the modified Penman-Monteith (PM) model

\begin{tabular}{|c|c|c|c|}
\hline ET model & Reference & Remarks & $\begin{array}{l}\text { Annual ET } \\
\text { value }(\mathrm{mm})\end{array}$ \\
\hline FAO PM & Allen et al. (1998) & $\begin{array}{l}\text { Food and Agriculture Organization's standardized form of the PM equation, } \\
\text { for a single crop species (alfalfa) under well-watered conditions }\end{array}$ & 1,807 \\
\hline Combination PM & Shuttleworth (1992) & $\begin{array}{l}\text { Only major model accounting for vegetation water-use effects } \\
\text { parameterized by Leaf Area Index and vegetation height }\end{array}$ & 1,502 \\
\hline Priestley-Taylor & German (2000) & Detailed meteorological model & 4,008 \\
\hline $\begin{array}{l}\text { Abtew's simple } \\
\text { radiation model }\end{array}$ & Abtew (2005a) & $\begin{array}{l}\text { Net radiation-based model formulated by Abtew for the northern } \\
\text { Everglades (herbaceous vegetation) and validated using lysimeters. }\end{array}$ & 1,602 \\
\hline Modified Turc model & Turc (1961) & Net radiation and temperature based model & 1,469 \\
\hline Bowen ratio & Hatton and Vertessy (1990) & Ratio of latent heat to sensible heat obtained from eddy covariance tower & 1,349 \\
\hline $\begin{array}{l}\text { Modified } \\
\text { combination PM }\end{array}$ & $\begin{array}{l}\text { Shuttleworth (1992) } \\
\text { and our addition }\end{array}$ & $\begin{array}{l}\text { Combination PM model modified to include ET reduction due to water } \\
\text { limiting conditions in the dry season }\end{array}$ & 1,366 \\
\hline
\end{tabular}

to wilting point (Lott and Hunt 2001), or in the case of coastal hammocks, salinity increases in the rhizosphere, typically in the dry season (Sternberg et al. 2007). Thus a sinusoidal function was added to the Shuttleworth equation to model the reduction of transpiration over late dry season caused by soilwater deficits in the freshwater part of the slough, as well as by increased groundwater salinity and decrease in the freshwater lens for buttonwood and coastal hammock communities (Saha et al. 2011). Here, $\theta$ increases from $60^{\circ}$ to $90^{\circ}$ in conjunction with decreasing water availability over the dry season and otherwise is equal to $0^{\circ}$ for the wet season/early dry season, when water limiting conditions do not exist.

Meteorological data for the models were obtained from four eddy flux towers within the ENP (Fig. 1) at Florida Coastal Ecosystems Long Term Ecological Research sites SRS6, SRS2, TsPH1 and TsPh7 (http://fcelter.fiu.edu/ research/sites/); data from SRS6 was available for the longest time period (2004-2008) and was thus chosen and compared with data from other sites. The SRS is dominated by sawgrass (Cladium jamaicense) alongwith extensive spikerush (Eleocharis spp.) and periphyton in the northern half and by mangroves (Avicennia germinans and Rhizophora mangle) in the southern half. LAI for sawgrass and mangrove was taken as 2 and 3, respectively. Sawgrass height was assumed to be $1 \mathrm{~m}$. Mangrove canopy heights vary from $18 \mathrm{~m}$ along the coast to $3 \mathrm{~m}$ inland (Simard et al. 2006; Castaneda 2010), and thus an average height of $9 \mathrm{~m}$ is taken for the entire mangrove zone (SRS4-SRS6). While other plant communities such as hardwood hammocks, swamp forests, pine rocklands, coastal hammocks and buttonwood embankments occur, their area in the SRS is much less than sawgrass and mangrove stands. Furthermore woody communities such as hammocks and pine rocklands have LAI values between 2 and 3 (Saha et al. 2009).

Change in Storage Hourly water level or stage data from 16 stations situated in SRS was obtained from EDEN
(USGS), adjusted to NAVD 1988 if originally referring to NGVD 1929 and then averaged over a 24-h period to get a daily stage value. Day-to-day and month-to-month level changes were calculated as the difference from 1 day to the next and difference between the levels on the last and first day of the month, respectively. The Thiessen polygon method was used to obtain a spatial average stage difference for the entire SRS using MATLAB functions. The changes in level were multiplied by the area of SRS to obtain corresponding changes in storage $(\Delta V)$.

Residual Net groundwater exchange being the unknown component of water budget is usually estimated from the residual after accounting for errors in each of the remaining water budget terms as described (e.g., Sutula et al. 2001). Errors could either lead to overestimates or underestimates of each of these terms; furthermore, errors in inputs may nullify some of the error in outputs upon summation of the budget. A conservative approach was taken whereby combined error was assumed as the sum of the absolute values of input and output errors which was then subtracted from the residual to yield the net groundwater exchange. For instance, an extreme case would be that the input data had negative error (errors detract from the true value of input data) while the output data were inflated by positive error. In this case the difference between the errors was maximal, in contrast to the other extreme where inputs were inflated and outputs were deflated. Thus residual=groundwater \pm error, where error $=$ absolute input errors + absolute output errors. Because ET is the only major water budget component that is estimated rather than directly measured, a sensitivity analysis was carried out on the water budget to observe the variation in groundwater discharge (residualerror) arising from using different models to estimate ET.

Surface Water and Groundwater Salinity Surface water salinity at the oligohaline ecotone results from mixing of 
marine waters (tides and brackish groundwater discharge), freshwater (surface flow and groundwater), and ET. The extent of saline water incursions is reflected by the vegetation transition from sawgrass (freshwater) to salinity-tolerant mangroves. Salinity, surface water level and groundwater level data were obtained from NWIS for station SH2 $\left(25^{\circ} 24^{\prime} 36.22^{\prime \prime} \mathrm{N}, 80^{\circ} 57^{\prime} 47.88^{\prime \prime} \mathrm{W}\right)$ located at the oligohaline ecotone between 2002 and 2008, where the surface water stilling well was a $30.5-\mathrm{cm}$ diameter PVC pipe set in sediment to bedrock and the groundwater well was a drilled bore hole cased with a 7.6-cm PVC riser and a $183-\mathrm{cm}$ long well screen set with $0.1 \mathrm{~cm}$ slots spaced $0.3 \mathrm{~cm}$ apart capped at the bottom within the shallow aquifer. Salinity data were obtained from conductivity measurements using a 3 YSI 600R conductivity and temperature probe (YSI, OH, USA). These data were lag correlated with various components of the water budget. Regressions, lag correlations, and time series analysis were performed using MATLAB (v. 7.9.0.529; R2009b). Lag correlations were calculated by stepping time series forwards and backwards and resolving the correlation coefficient $(R)$ at each step. Statistical significance was tested at the $95 \%$ confidence interval $(p=0.05)$ using a phase-randomization method based on (Ebisuzaki 1997) to account for non-zero autocorrelations.

Surface Water and Groundwater Levels Differences between groundwater levels and surface water levels indicate the potential direction for a vertical transfer of water between the two water bodies. When the groundwater levels are higher than the surface water levels, there is the potential for groundwater discharge to the surface water. Similarly, when the surface water level is higher than the groundwater there is the potential for surface water to recharge the underlying aquifer. This data indicates groundwater-surface water interactions independent of the water budget approach. Surface water and groundwater data was obtained from $\mathrm{SH} 2$ (same as the salinity data as described above) for the period 2000-2008. The difference in levels (groundwater level-surface water level) was averaged monthly over 2000-2008.

Data Processing For all parameters of the water budget, stations with erroneous ad/or missing data greater than $5 \%$ of the record set were excluded from the analysis. Stations with missing data less than $5 \%$ of the total were linearly gap filled.

\section{Results}

Rainfall A seasonal and bimodal pattern was observed in all 7 years of rainfall data (Fig. 2a) with high rainfall occurring in the wet season (June-October). While the rainfall for 2002-2008 averaged over the SRS was similar to a longer term average annual rainfall $(1,366 \mathrm{~mm}$, based on 1980-2009 at Royal Palm Ranger Station, ENP), inter-annual variability was observed (Table 3; Fig. 2 (top)) with 2002 receiving the lowest $(1,142 \mathrm{~mm})$ and 2005 the highest $(1,448 \mathrm{~mm})$. While daily rainfall varied considerably between the stations, indicating spatial patchiness in precipitation on a daily time scale, monthly rainfall amounts did not vary greatly between stations. Monthly rainfall did however vary from year to year (Fig. 5). Uncertainty in rainfall data is due to several factors: instrument precision $(0.254 \mathrm{~mm}$ on a daily reading translates to $92 \mathrm{~mm} /$ year), spatial variability (insignificant on a monthly scale), and inter-annual variation.

Inflow and Discharge from SRS Over 2002-2008, surface water inflows commenced well into the wet season and lagged behind rainfall by 1-2 months (Figs. 2 (middle), 4, 5). There was considerable inter-annual variation in the inflows, with the high of $691 \mathrm{~mm}$ in 2005 coinciding with the highest precipitation in 2002 through 2008, part of which was contributed by the hurricanes Katrina and Wilma) while almost no inflow occurred in 2007 (Table 3). Inflows were $25-50 \%$ of discharges from SRS in each year (Table 3; Fig. 4) with the exception of 2003. Outflows varied from $1,399 \mathrm{~mm}$ in 2005 , the year with the highest rainfall, to a low of $502 \mathrm{~mm}$ in 2003 (Table 3).

Evapotranspiration The Shuttleworth PM model yielded ET values that varied seasonally: 5-7 $\mathrm{mm} /$ day in summer and 1-4 mm/day in winter (Figs. 3, 4, and 5).Mangrove communities were associated with higher ET than sawgrass on account of greater LAI and vegetation height (Fig. 3). Other models showed a similar seasonal variation but with different magnitudes (Table 1); for instance the FAO PM model had higher ET values than the Shuttleworth PM model, possibly reflecting the agricultural bias of the FAO PM model that is designed to work for a single species under well-watered conditions; thus the FAO PM model yielded similar potential ET estimates for South Florida as the USGS (http://sofia.usgs.gov/eden/evapotrans.php). The Priestley-Taylor equation yielded values twice as large; this model has been reported to overestimate ET in humid areas in summer (Yoder et al. 2005; Suleiman and Hoogenboom 2007). ET estimates obtained from latent heat flux data showed the same seasonal pattern as the other models but was lower in magnitude as has been noticed elsewhere (Bidlake et al. 1996) whereby latent heat based measurements are almost always lower than values yielded by meteorological vapor transport models.

On account of several hurricanes and tropical storms that passed through the area over 2004-2007, the weather 
Fig. 2 Raw data for selected water budget components for Shark River Slough, ENP. Top, monthly rainfall averaged over Shark River Slough; also shown is the 30-year average monthly rainfall at Royal Palm Ranger Station, ENP (with less than 4\% data missing). Middle, monthly inflows (S12s and S333) and outflows (five major rivers into the Gulf of Mexico). Bottom, daily water level or stage averaged over the SRS
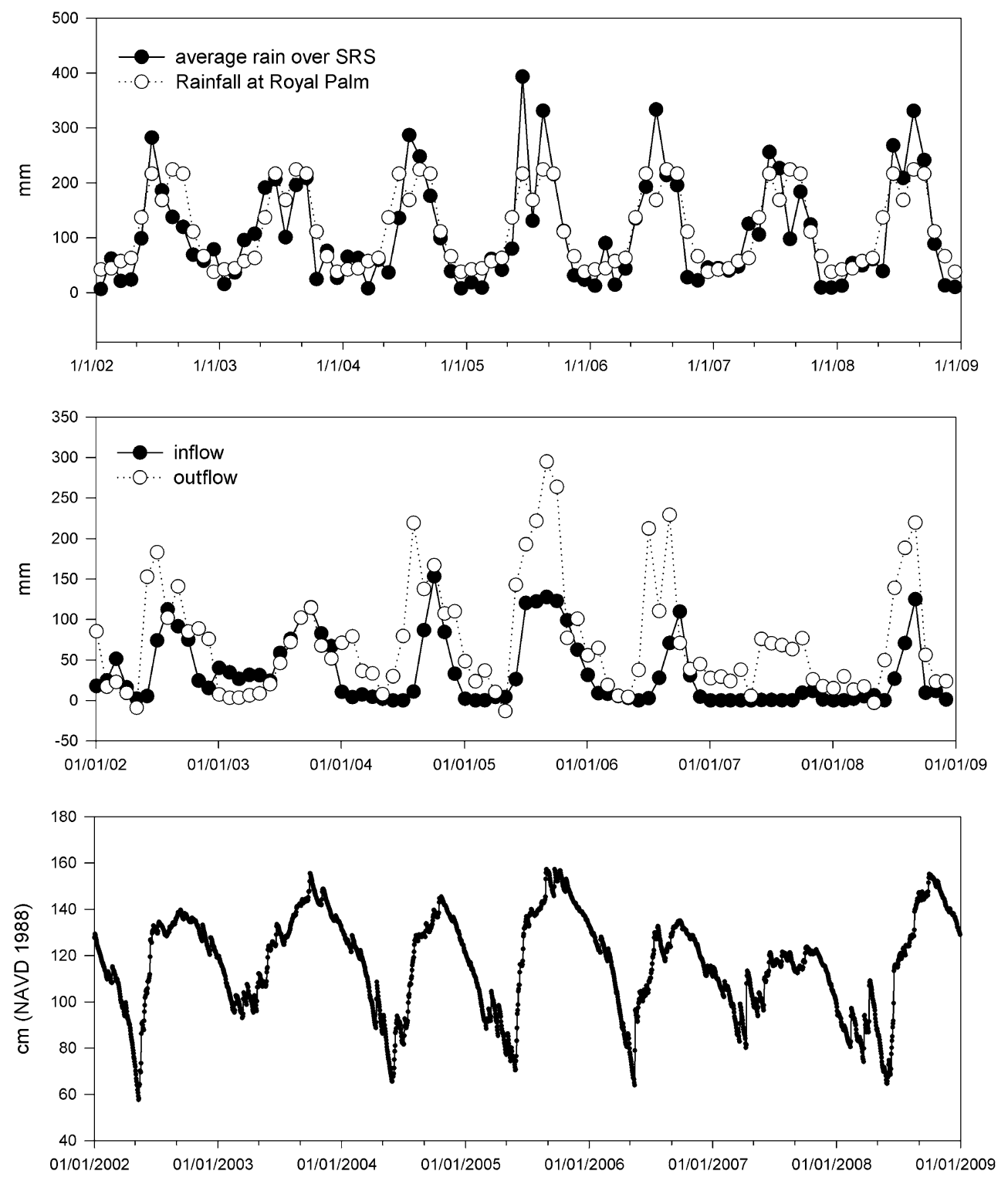

towers were severely damaged, leading to large gaps in data over this period. Hence, while we calculated ET over the entire 2004-2008 data availability period, for the budget we consider 2008 as a "model" year with complete daily ET estimates calculated from SRS6 eddy flux tower data. The monthly ET values obtained by Abtew's simple radiation model for 2004 and 2008 did not differ significantly $(p>0.99)$. ET calculated from SRS6 meteorological data can be considered representative of SRS, because net radiation, the single most important driver of ET in the Everglades (Abtew 1996) was found to be very similar at the four eddy flux towers spread over an area of almost $5,000 \mathrm{~km}^{2}$ in the month of August 2008 when we had data from all four weather towers. Error in ET measurements stems from instrumental precision (taken as 5\% from Price et al. 2006) as well as from differences in vegetation composition and soil moisture at a given instant of time (Fig. 3).
Water Levels Water levels in SRS varied by less than $1.5 \mathrm{~m}$ on a seasonal basis (Fig. 2c). The highest water levels were observed in September-November of each year. Water levels were at their lowest in May of each year.

Water Budget and Net Groundwater Discharge The annual change in water storage in SRS varied from deficit to surplus, from a net gain of $303 \mathrm{~mm}$ at the end of 2008 to a net loss of $216 \mathrm{~mm}$ in 2006 (Table 3). The magnitude of annual change in water storage was orders of magnitude lower than the other water budget components (Fig. 4). Over the period studied, 2002-2008, rainfall was the largest input, averaging $1,295 \mathrm{~mm} /$ year while ET was the largest output averaging $1,367 \mathrm{~mm} /$ year (Table 3 ). Outflows exceeded inflows and all other inputs combined, which led to a net groundwater input into the SRS (termed Groundwater Discharge or GWD) on an annual basis. 


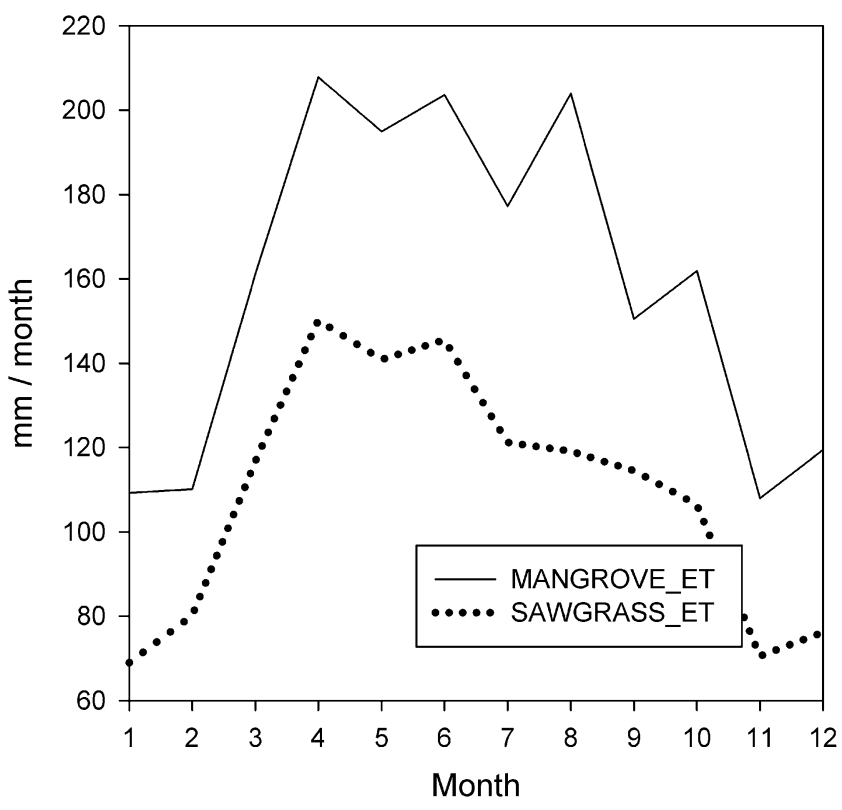

Fig. 3 Monthly evapotranspiration estimates obtained by the Shuttleworth PM model for mangrove and sawgrass, the dominant vegetation communities in the Shark River Slough. The difference in vegetation communities were parameterized by LAI values of 3 and 2 as well as by vegetation height of 9 and $1 \mathrm{~m}$ for mangroves and sawgrass, respectively

GWD varied seasonally, with the largest inputs occurring in May-July, and a net recharge or input from the slough surface water in Jan-April (Fig. 4). There was a large annual variation with the highest value of net GWD into the SRS $(673 \mathrm{~mm})$ in 2008 and a net recharge of groundwater $(88 \mathrm{~mm})$ occurring in 2003 (Table 3; Fig.5). The estimate of GWD varied with the ET model used (Table 1). The values of GWD obtained in the water budget result from the selection of the modified Shuttleworth PM model to estimate ET.
Surface Water and Groundwater Salinity Surface water salinity varied seasonally between 0 and 23.5 psu. Groundwater salinity also varied seasonally, with the maximum annual values increasing from less than 5 psu in 2003 to about 15 psu in 2008 (Fig. 6). With monthly data, analysis by lag correlation indicated that surface water salinity in SRS had a significant positive correlation with GWD (Fig. 7) when leading by 1 month $(p<0.03)$. The same pattern was demonstrated in the daily data, where the surface water salinity expressed a significant positive correlation with GWD when leading by $24-34$ days $(p<0.05)$.

Surface Water and Groundwater Level Both groundwater and surface water levels at site SH2 co-vary over monthly and yearly time scales (Fig. 8 (top)). Daily groundwater level is consistently higher than surface water in early wet season (end of May to August). Monthly averages indicated that at $\mathrm{SH} 2$, groundwater discharge to the surface water was dominant in June-August, with surface water recharging the groundwater being dominant during the other months (Fig. 8 (bottom)).

\section{Discussion}

Seasonal Patterns All the components of the water budget varied seasonally with higher values typically occurring in the wet season months (June-October). This seasonal variability is most evident in the glyphplot of the water budget terms (Fig. 5) where the monthly glyphs (polygons containing the monthly water budget components on spokes) are much larger over the wet season in all 7 years.
Fig. 4 Average monthly water budget components (2002-2008). Negative $y$-axis values signify outputs from the Shark Slough

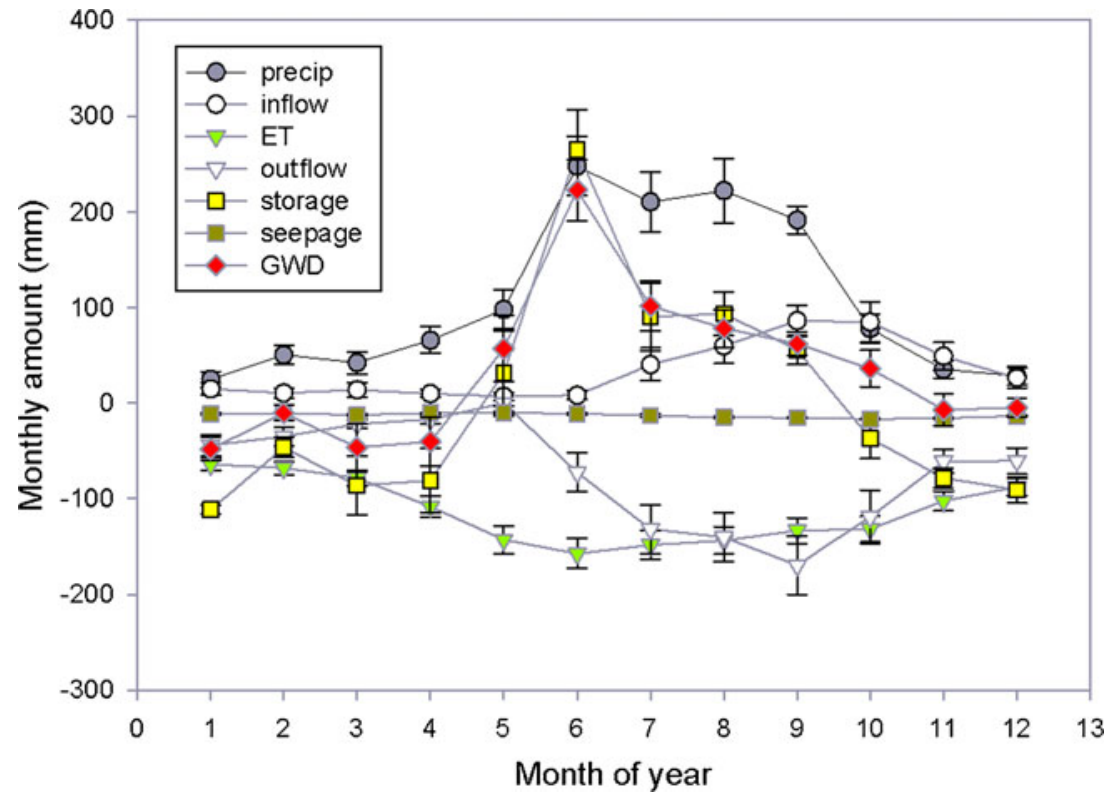




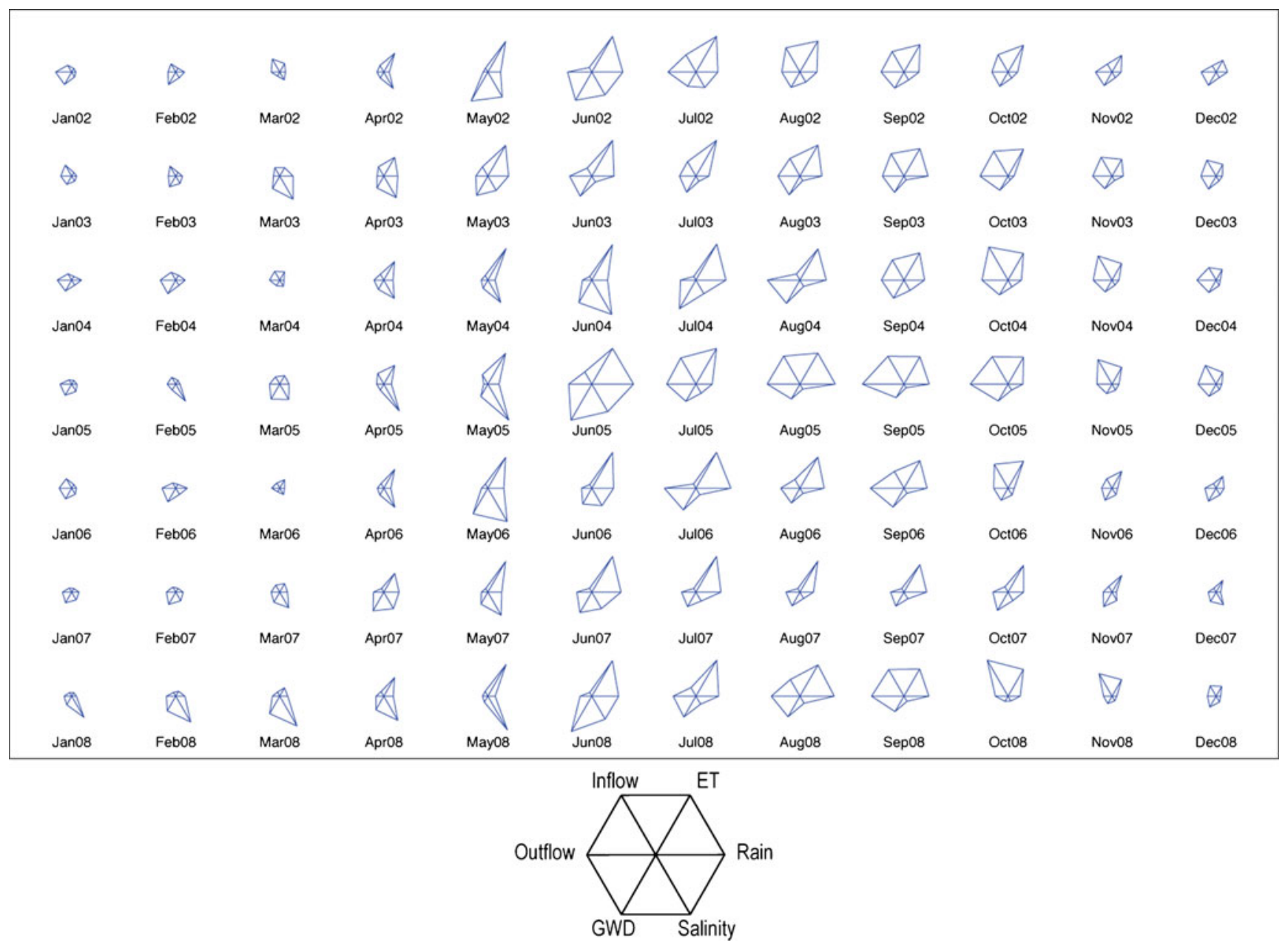

Fig. 5 Glyph plot of the monthly water budget components (20022008). The spokes of each glyph (polygon) represent the magnitude of each variable (independently standardized by variable from 0 to 1 ) for the indicated month. For example, the glyph for Sept 2008 represents high rainfall, moderate ET, high inflow, high outflow, low GWD, and very low salinity
The glyphplot also illustrates the considerable inter-annual variation in water budget components, part of which could be driven by regional climate cycles; for instance 2004 and 2005 had active hurricane seasons, 2006-2007 were much drier than usual while the winter of 2009-2010 saw higher than normal precipitation in accordance with the positive phase of the El Niño Southern Oscillation (Ropelewski and Halpert 1986; Childers et al. 2006; Moses et al., submitted). Furthermore, water management activities introduce an element of apparent randomness in inflows that in turn affect other components.

The wet season commences in June and has a bimodal rainfall distribution (Fig. 2 (top)) lasting until November; thereafter rains are scattered and sporadic. Flow in rivers discharging to the Gulf of Mexico responds to precipitation, increasing between May and June, and declining after December until a net tidal seawater input from the Gulf of Mexico occurs in May in most years. Other processes such as evapotranspiration, inflows and net groundwater dis- charge also influence discharge. Inflows through hydraulic structures controlled by the South Florida Water Management District commence only in July in response to rainfall and water levels in the water conservation areas upstream of ENP; inflows decrease from October onwards until being practically nonexistent after December. ET increases from February in response to increasing solar radiation. In the Everglades, plants are seen to have active transpiration through much of the dry season as has been observed in studies of plant water uptake in hardwood hammocks and pine rocklands (Ewe et al. 1999; Saha et al. 2009; Villalobos 2010), tree islands and swamp forests (Wang et al. 2010; Sullivan et al. 2010), and mangroves (Barr et al. 2010). There can be a reduction in transpiration in late dry season in part of SRS caused by soilwater deficits and salinity increases (Sternberg et al. 2007; Saha et al. 2011); soilwater deficits can occur in the outer or shallower areas of the SRS that dry earlier while increasing rhizosphere salinity lowers transpiration in freshwater-dependant plants 
Table 2 Parameters for the Penman-Monteith equation (Shuttleworth 1992)

\begin{tabular}{|c|c|c|}
\hline Variable & Description & Notes: \\
\hline$e_{s}$ & $\begin{array}{l}\text { Saturated vapor pressure at the measurement height in } \\
\text { kilopascals }(\mathrm{kPa}) . T \text { is the mean air temperature in } \\
\text { degrees Celsius }\left({ }^{\circ} \mathrm{C}\right)\end{array}$ & $e_{\mathrm{s}}=0.6108 \exp \left(\frac{17.27 T}{237.3+T}\right)$ \\
\hline$\Delta$ & $\begin{array}{l}\text { The gradient of the actual vapor pressure with the } \\
\text { mean air temperature } e_{\mathrm{S}}\left(\text { in } \mathrm{kPa}^{\circ} \mathrm{C}^{-1}\right)\end{array}$ & $\Delta=\frac{4,098 e_{s}}{(237.3+)^{2}}$ \\
\hline$A$ & Energy budget for a unit area. $A$ is the available energy & $A=R_{\mathrm{n}}-G-S-P-A_{\mathrm{d}}$ \\
\hline$A_{\mathrm{d}}$ & $\begin{array}{l}\text { Loss of energy associated with horizontal air movement. } \\
\text { Significant in an oasis situation, generally neglected }\end{array}$ & Units are $\mathrm{MJ} \mathrm{m}^{-2}$ day $^{-1}$ \\
\hline$R_{\mathrm{n}}$ & Net incoming radiant energy & Units are $\mathrm{MJ} \mathrm{m}^{-2}$ day $^{-1}$. Obtained at $\mathrm{TSPh} 7 \mathrm{~b}$ \\
\hline$G$ & Outgoing heat conduction into the soil & $G=\operatorname{cs}^{*} \operatorname{ds}\left(T_{2}-T_{1}\right) / \Delta t$. Units are $\mathrm{MJ} \mathrm{m}^{-2}$ day $^{-1}$ \\
\hline cs & Soil heat capacity & $2.1 \mathrm{MJ} \mathrm{m}^{-3 \circ} \mathrm{C}^{-1}$ \\
\hline ds & Estimated effective soil depth (m) & For daily temperature fluctuations, a value of 0.18 can be assumed \\
\hline$S$ & Energy temporarily stored within the volume & Often neglected except for forest \\
\hline$P$ & Energy absorbed by biochemical processes in the plants & Typically taken as $2 \%$ of net radiation \\
\hline$D$ & Vapor-pressure deficit & $D=\left[\left(e_{s}^{*} T_{\max }+e_{s}^{*} T_{\min }\right) / 2\right]^{*}(1-\mathrm{RH}) / 100 \mathrm{RH}=$ relative humidity \\
\hline$e_{\mathrm{a}}$ & Actual vapor pressure $(\mathrm{kPa})$ & $\operatorname{In}\left(\frac{z_{\mathrm{u}}-d}{\mathrm{z}}\right) \operatorname{In}\left(\frac{\mathrm{z}_{\mathrm{e}}-d}{\mathrm{z}}\right)$ \\
\hline$r_{\mathrm{a}}$ & Aerodynamic resistance $\left(\mathrm{s} \mathrm{m}^{-1}\right)$ & $r_{\mathrm{a}}=\frac{\left(z_{0 \mathrm{~m}}\right)\left(z_{0 \mathrm{v}}\right)}{k^{2} U_{\mathrm{z}}}$ \\
\hline$r_{\mathrm{s}}$ & Surface resistance of the land cover $\left(\mathrm{s} \mathrm{m}^{-1}\right)$ & One approximation is $200 / \mathrm{L} \mathrm{s}^{-1} \mathrm{~m}^{-1}$ \\
\hline$Z_{\mathrm{u}}$ & Height of the wind speed measurements (m) & \\
\hline$Z_{\mathrm{e}}$ & Height of the humidity measurements (m) & \\
\hline$U_{\mathrm{z}}$ & Wind speed $\left(\mathrm{ms}^{-1}\right)$ & \\
\hline$Z_{0 \mathrm{~m}}$ & Roughness length for momentum transfer (m) & $Z_{0 \mathrm{~m}}=0.123 h_{\mathrm{c}}$ \\
\hline$Z_{0 \mathrm{v}}$ & Roughness length for vapor transfer (m) & $Z_{0 \mathrm{v}}=0.0123 h_{\mathrm{c}}$ \\
\hline$D$ & zero-plane displacement height $(\mathrm{m})$ & $d=0.67 h_{\mathrm{c}}$ \\
\hline$K$ & Van Karman constant $(=0.41)$ & \\
\hline$h_{\mathrm{c}}$ & Vegetation height (m) & \\
\hline$\rho_{\mathrm{a}}$ & Sensible heat $\left(\mathrm{kg} \mathrm{m}^{3}\right)$, density of air & $\rho_{\mathrm{a}}=3.486 \frac{P}{275+T}$ \\
\hline$C_{\mathrm{p}}$ & $\begin{array}{l}\text { Specific heat of air at constant pressure, taken as } \\
1.01 \mathrm{KJ} \mathrm{kg}^{-1} \mathrm{~K}^{-1}\end{array}$ & \\
\hline$P$ & Atmospheric pressure in $\mathrm{kPa}$ & \\
\hline$T$ & Mean air temperature in degrees Celsius & \\
\hline$\Gamma$ & Psychrometric constant $\left(\mathrm{kPa}^{\circ} \mathrm{C}^{-1}\right)$ & $\gamma=\frac{C_{\mathrm{p}} P}{\in \lambda} 10^{-3}=0.0016286 \frac{P}{\lambda}$ \\
\hline$E$ & $\begin{array}{l}\text { Ratio of the molecular weight of water vapor to that } \\
\text { for dry air }\end{array}$ & 0.622 \\
\hline$\Lambda$ & Latent heat of vaporization of water $\left(\mathrm{MJ} \mathrm{kg}^{-1}\right)$ & $\lambda=2.501-0.002361 T_{\mathrm{s}}$ \\
\hline
\end{tabular}

Table 3 Annual water budget components (2002-2008) in millimeters/year for Shark River Slough, Everglades National Park, including average and standard error of the mean (SEM) computed over the entire 7-year period

\begin{tabular}{lrrrrrrrrr}
\hline Budget component $(\mathrm{mm})$ & 2002 & 2003 & 2004 & 2005 & 2006 & 2007 & 2008 & Average & SEM \\
\hline Rain & 1,142 & 1,285 & 1,224 & 1,448 & 1,325 & 1,269 & 1,375 & 1,295 & 38 \\
ET & 1,367 & 1,367 & 1,367 & 1,367 & 1,367 & 1,367 & 1,367 & 1,367 & 0 \\
Inflow & 509 & 688 & 396 & 691 & 303 & 24 & 258 & 410 & 119 \\
Outflow & 952 & 502 & 1,077 & 1,399 & 892 & 521 & 771 & 873 & 91 \\
Seepage & 166 & 178 & 177 & 168 & 148 & 115 & 149 & 157 & 8 \\
Storage change & -78 & 131 & -109 & 117 & -216 & -116 & 303 & 5 \\
Groundwater & 449 & -88 & 585 & 572 & 270 & 336 & 673 & 400 & 97 \\
Total error & 306 & 292 & 306 & 339 & 292 & 258 & 283 & 297 & 9 \\
\hline
\end{tabular}

Negative values for storage mean a net decrease in storage over the year. We have taken the 2008 value of ET for all years. Inflow and outflows have been expressed as millimeters per year by dividing the total volume by the area of Shark River Slough. Total error refers to the difference between the residual (obtained by summing all known inputs and outputs) and groundwater discharge 
Fig. 6 Salinity in surface water and groundwater at USGS site SH-2, and FCE LTER site SRS-4

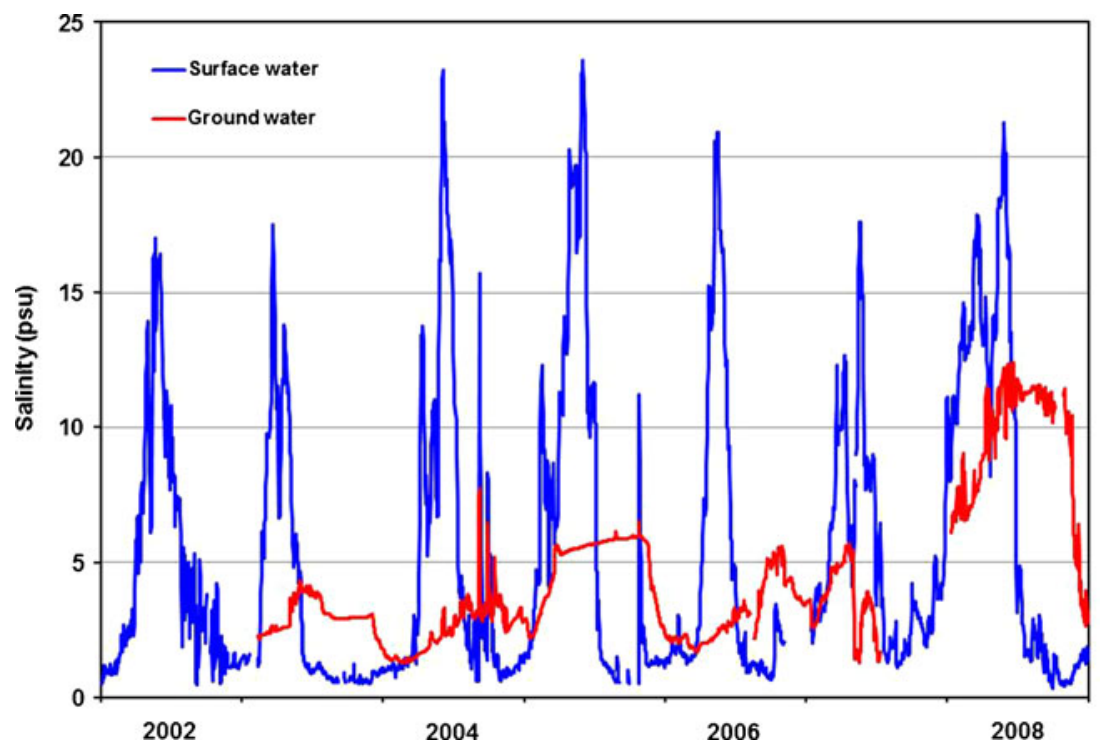

in the estuarine zone (coastal hammocks and buttonwoods). Nevertheless, ET is the highest in May-July (Figs. 3, 4, and 5), reflecting the period of highest net radiation, thereafter offset by increasing cloudiness and relative humidity.

Groundwater Influx into Slough Groundwater discharge starts in May at the end of the dry season, peaks in JuneJuly and then decreases throughout the remainder of the year (Figs. 4 and 5). Groundwater discharge to SRS would be expected to occur as freshwater in the northern reaches of SRS adjacent to Tamiami Trail as well as brackish water further downstream in the estuarine zone. Tamiami Trail acts as a levee/dam along the north side of SRS causing a large hydraulic gradient between higher water levels in the Tamiami Canal on the northern side of the trail as compared to the lower ground surface elevation of SRS on the south side of the canal (Harvey and McCormick 2009). Fresh GWD along the south side of the Tamiami Trail to the SRS
Fig. 7 Monthly groundwater discharge to SRS and monthly surface water salinity at $\mathrm{SH} 2$ (the oligohaline ecotone) averaged over 2002-2008

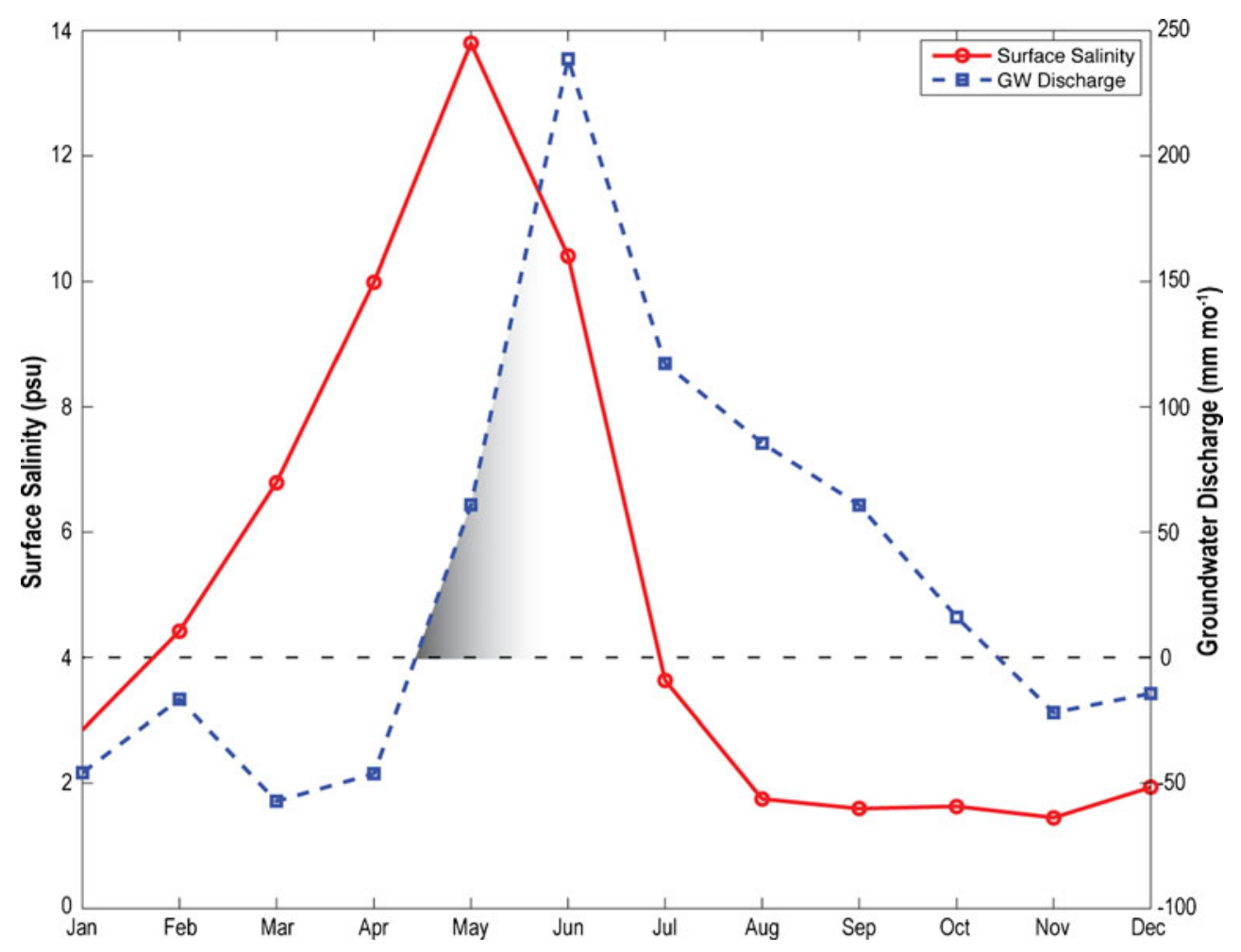




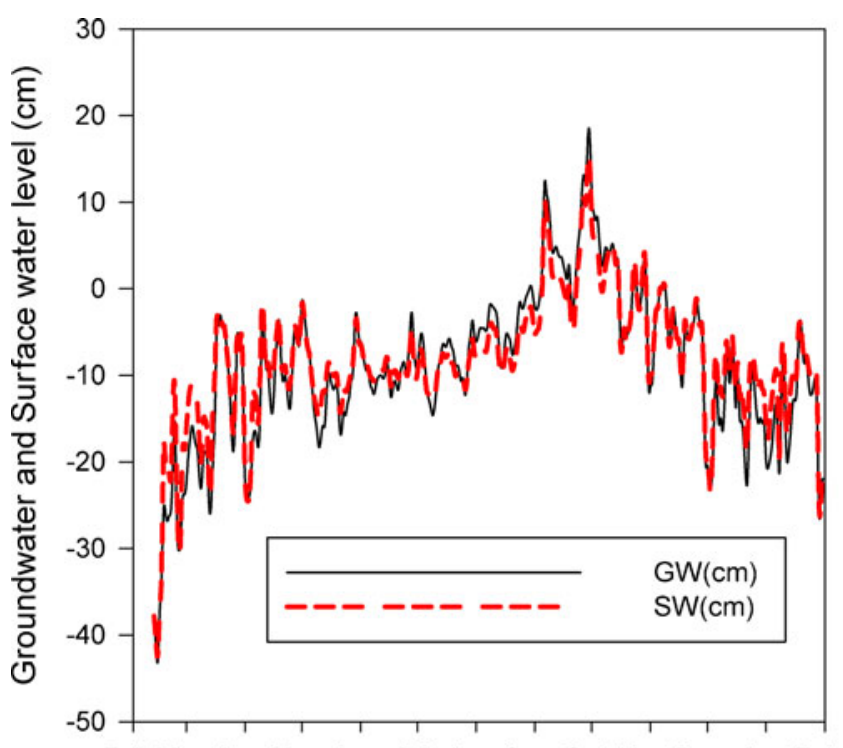

Feb Mar Apr May Jun Jul Aug Sep Oct Nov Dec Jan Feb

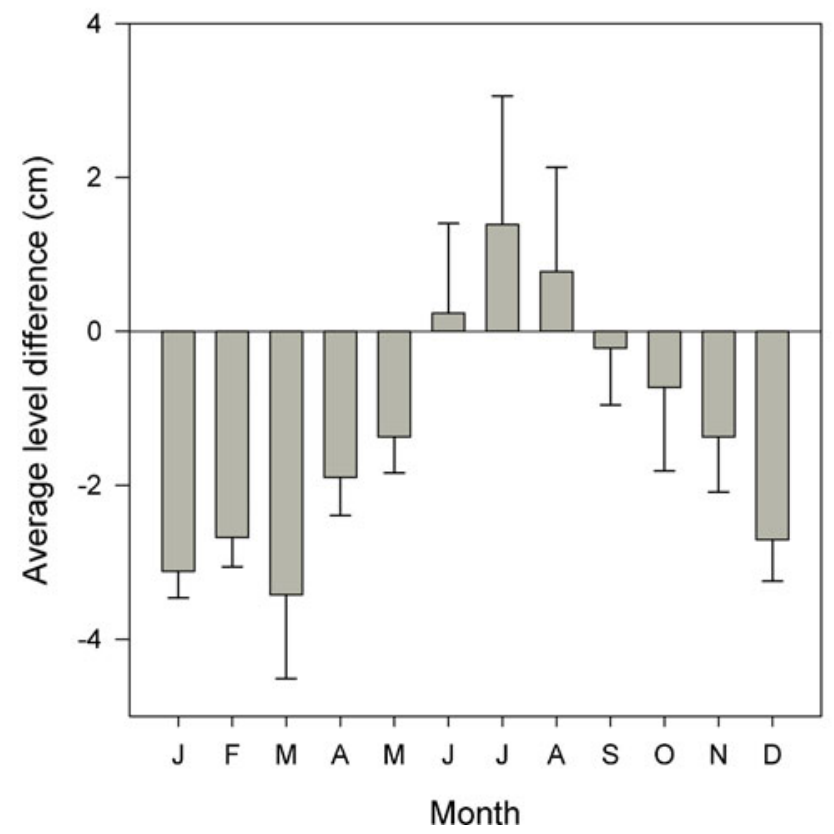

Fig. 8 Top, daily groundwater (black solid line) and surface water level (red dashed line) in $\mathrm{cm}$ relative to NAVD 1988 at USGS site SH2. Bottom, monthly average difference between groundwater level and surface water level calculated over 2000-2008 and expressed in $\mathrm{cm}$ at SH2. Positive values of this difference, as seen in June-Aug, signify that the groundwater was higher than surface water on average in this time every year. Error bars signify the standard error of the mean

is expected in response to the hydraulic gradient, and may explain the elevated concentrations of phosphorus observed in the surface water site SRS-1 (Fig. 1) reported by Childers et al. (2006) since groundwater in the region typically has higher concentrations of phosphorus as compared to the overlying surface water (Price et al. 2006). Brackish GWD is expected along the mangrove ecotone region of southern
SRS due to the hydrodynamics of seawater intrusion (Price et al. 2006). The flat topography of the southern Everglades combined with the low water inflows along Tamiami Trail into SRS has allowed seawater to intrude as much as $30 \mathrm{~km}$ inland from the Gulf of Mexico, corresponding approximately with the extent of mangroves inland (Price et al. 2006; Fitterman et al. 1999). Coastal brackish GWD has been observed in Taylor Slough, the other drainage basin of ENP (Sutula et al. 2001; Price et al. 2006; Fig. 1) particularly during the dry season from January all the way to the early wet season until July (Zapata-Rios 2009), similar to what is estimated for SRS. Furthermore in Taylor Slough, coastal brackish GWD were higher and more variable closer to the coastline (Zapata-Rios 2009).

Surface water salinity at the boundary of the mangrove/ sawgrass ecotone of SRS (at SRS-4) increases in AprilMay, with the peak in surface water salinity occurring about a month prior to the greatest groundwater discharge (Fig. 7). The higher salinity in the surface water as compared to the groundwater at SRS-4 indicates that a large portion of surface salinity is related to Gulf of Mexico water inflows through rivers up the SRS as opposed to the lower salinity groundwater (Fig.6). May also corresponds to the lowest outflows from the SRS rivers draining to the Gulf of Mexico (Figs. 2, 4); indeed the net flows during much of that time are negative, indicating seawater flowing inland through the creeks. Geochemical analysis confirms that most of the surface water in SRS is a mixture of fresh water and Gulf of Mexico water (Price et al. 2006). Although the coastal brackish GWD in the southern reaches of Shark Slough is not enough to affect the overall surface water salinity, the contribution of groundwater is not negligible and can account for over $200 \mathrm{~mm}$ across SRS in the month of July (Fig. 7). In June, surface water salinity decreases rapidly at SRS-4, indicating the arrival of large volumes of freshwater from precipitation and runoff from upstream. Groundwater discharge increases until June, suggesting increased baseflow accompanying the surface freshwater flows from upstream. Thereafter groundwater discharge to the slough decreases, most likely because of higher surface water levels in SRS.

The conclusion of groundwater discharge to the slough is also supported by an examination of groundwater and surface water levels (Fig. 8). The hydraulic connection between the two reservoirs is indicated by the co-varying groundwater and surface water levels (Fig. 8 (top)); however, slight differences in the water levels indicates the potential direction for a vertical transfer of water between the two water bodies. For instance, daily groundwater levels are higher than surface water mostly in the early wet season (June-August) as observed i Fig. 8 (top). This pattern is repeated over 2000-2008 whereupon monthly averages of the difference between groundwater 
and surface water are positive over the same period (Fig. 8 bottom), indicating groundwater discharge to the surface water reservoir.

Increased Inflow Is Essential for Flow and Storage of Water Freshwater discharge not only restrains seawater intrusion into the coastal aquifer but also lowers the salinity of these coastal shallow basins, thereby maintaining conditions for seagrass and marine organisms that use these areas as nurseries (Wanless et al. 1994). Decreased freshwater inflows lead to increased brackish groundwater discharge inland along the coast that in turn can threaten coastal plant communities intolerant of salinity. Over the study period (2002-2008), rainfall was the largest input, while ET was the largest output (Table 3), both of a similar magnitude, as has been noticed in other studies in the Everglades (e.g., Abtew 1996). From a purely numerical volume perspective, inputs of water via rain are almost nullified by ET losses; hence, increased inflows as part of upstream water management should result in greater outflows as well as greater storage, although probably not on a 1:1 basis since there may also be increased seepage east under the L31 levee on the eastern boundary. On average, GWD equated to surface water inflows across Tamiami Trail and roughly $30 \%$ of rainfall. The budget supports the widely held contention that increased inflows are required to maintain the Everglades ecosystem inside ENP that is especially critical under the scenario of accelerated sea level rise (Wanless et al. 1994).

Evapotranspiration and the Need for Field Measurements ET is the largest water loss in SRS, resulting from the high subtropical radiation, prevailing ocean breezes and the yearround availability of water in much of the slough. Daily ET values predicted by all the models (with the exception of Priestley-Taylor) and latent heat based calculations are in the same order as field measurements using lysimeters in the Everglades marshes north of the ENP (German 2000; Abtew 1996, 2005a): 2-4 mm/day in January and February that increased to 5-7 mm/day in May-July. Annual estimates by these models $(1,350-1,600 \mathrm{~mm})$ are similar to $1,300-1,400 \mathrm{~mm}$ as reported by Abtew et al. (2005b) and Huebner (2008). However, such variability in ET estimates from different approaches reflects the difficulties in accurately estimating ET in wetlands (Rushton 1996, Shoemaker et al. 2008). There is no instrument that can directly measure evapotranspiration; although lysimeters have been deemed suitable for wetlands with herbaceous vegetation (Koerselman and Beltmann 1988), they are impractical where there is large woody vegetation. The complexity and dynamic nature of interactions of incident radiant energy, surface heat capacitive/reflective properties, atmospheric humidity and wind velocity, together with the tremendous variability involved in each of these parameters results in this variability being transmitted to ET (Abtew 1996; Lott and Hunt 2001). Furthermore, the variety of vegetation types in the Everglades can affect transpiration which is related to the amount of photosynthesizing biomass per unit area, species-specific water-use efficiencies and seasonal water use arising from phenology. For instance, trees on tree island heads draw in groundwater from the surrounding marsh in the dry season (McCarthy 2006; Saha et al. 2009; Sullivan et al. 2010), suggesting higher water uptake rates per unit area than surrounding sawgrass and slough vegetation, thus resulting in higher transpiration. It remains to be seen, however if the greater transpiration on tree islands is countered by higher open water evaporation in marshes. While German (2000) found no significant difference in ET between sawgrass marshes and open water sloughs, with vegetated areas showing a decrease in evaporation but an increase in transpiration, German mentions that the study did not include the mangrove-dominated estuarine areas that have higher foliar biomass per unit area (LAI). It is very likely that the presence of large woody vegetation in wetlands can increase evapotranspiration per unit area, as predicted by the results from the Shuttleworth PM model. While the Shuttleworth PM equation takes into account LAI and vegetation height, to which we add a water stress function to decrease ET due to water limiting conditions in the dry season, it would be highly desirable to compare model results with field data, despite uncertainties inherent in field techniques of water transport measurement. In addition to eddy covariance-based latent heat measurements, direct plant water uptake measurement techniques such as sapflow measurements in conjunction with diurnal groundwater level changes (e.g., Villalobos 2010), transpiration measurements and leaf water potentials, the last parameter needed is to identify periods when water may be limiting in the wetland (e.g., Kostner 2001) thereby getting a more realistic ET estimate from Potential ET estimates.

\section{Conclusions}

Each of the major water inputs and outputs to the SRS have been quantified over 2002-2008 on a daily, monthly and yearly basis. ET and net GWD, the two major components that cannot be measured directly have been estimated: ET by means of a suite of models while GWD was obtained from the water budget calculations. While ET estimates are similar to field observations in grassy wetlands using lysimeters, there is a need for further field observations of ET in different woody communities.GWD is calculated to be around $400 \mathrm{~mm} /$ year, between a quarter and a third of 
the annual precipitation to SRS. Monthly budgets indicate that GWD to the SRS is greatest in the later part of the dry season (May-July) but also occurs to a lesser extent in August and September. During the other months of the year, groundwater is recharged by surface water in SRS. The budget results also support increasing surface water inflows to maintain the Everglades ecosystem.

Acknowledgments The authors would like to thank the Florida Coastal Ecosystems Long Term Ecological Research Project (FCELTER), United States Geological Survey, Everglades National Park and the South Florida Water Management District for making data available for this analysis. A portion of A. Saha's, C. Moses and R.M. Price's time was supported by NSF grant no. DBI-0620409. Dr. Price was also supported by the NASA WaterSCAPES project. This is SERC Contribution \#533.

\section{References}

Abtew, W. 1996. Evaporation measurements and Modeling for three wetland systems in South Florida. Journal of the American Water Resources Association 32(3): 465-473.

Abtew, W. 2005a. Evapotranspiration in the Everglades: Comparison of Bowen Ratio Measurements and Model Estimations. In ASAE 2005 Meeting Presentation Paper no. 052188.

Abtew, W., S. Huebner, and V. Ciuca. 2005. Hydrology of the Everglades protected area. 2004 Everglades consolidated report chapter 5. West Palm Beach: South Florida Water Management District.

Allen, R.G., L.A. Pereira, D. Raas, and M. Smith 1998. FAO Irrigation and Drainage Paper 56, Food and Agriculture Organization (FAO), Rome, Italy.

Barr, J.G., V. Engel, J.D. Fuentes, J.C. Zieman, T.L. O’Halloran, T.J. Smith III, and G.H. Anderson. 2010. Controls on mangrove forest-atmosphere carbon dioxide exchanges in western Everglades National Park. Journal of Geophysical Research 115 (G02020): 14.

Becht, R., and D.M. Harper. 2002. Towards an understanding of human impact upon the hydrology of Lake Naivasha, Kenya. Hydrobiologia 488: 1-11.

Bedient, P.B., W.C. Huber, and B.E. Vieux. 2008. Hydrology and floodplain analysis, 4th ed, 795. Upper Saddle River: PrenticeHall.

Bidlake, W.R., W.M. Woodham, and M.A. Lopez. 1996. Evapotranspiration from areas of native vegetation in west-central Florida. USGS Water Supply Paper 2430: 35.

Butchart, H.M.S., et al. 2010. Global biodiversity: Indicators of declines. Science. doi:10.1126/science.1187512.

Camacho-B, S.E., A.E. Hall, and M.R. Kaufmann. 1974. Efficiency and regulation of water transport in some woody and herbaceous species. Plant Physiology 54: 169-172.

Carter, V. 1986. An overview of the hydrological concerns related to wetlands in the United States. Canadian Journal of Botany 64: 364-374.

Castaneda, E. 2010. Landscape patterns of community structure, biomass and net primary productivity of mangrove forests in the florida coastal Everglades as a function of resources, regulators, hydroperiod, and hurricane disturbance. Ph.D. dissertation, Louisiana Agricultural and Mechanical University. p 765.

Childers, D.L., J.N. Boyer, S.E. Davis, C.J. Madden, D.T. Rudnick, and F.H. Sklar. 2006. Relating precipitation and water management to nutrient concentration patterns in the oligotrophic "upside down" estuaries of the Florida Everglades. Limnology and Oceanography 61(1): 602-616.

Dadaser-Celik, F., H.G. Stefan, and P.L. Brezonik. 2006. Dynamic hydrologic model of the Ortuluakar marsh in Turkey. Wetlands 26(4): 1089-1102.

DeAngelis, D.L., J.C. Trexler, C. Cosner, A. Obaza, and F. Jopp. 2010. Fish population dynamics in a seasonally varying wetland. Ecological Modelling 221(8): 1131-1137.

Donders, T.H., P.M. Gorissen, F. Sangiorgi, H. Cremer, F. Wagner-Cremer, and V. McGee. 2008. "Three- hundred-year hydrological changes in a subtropical estuary, Rookery Bay (Florida): Human impact versus natural variability". Geochemistry, Geophysics, Geosystems 9 (Q07V06): 15.

Duever, M.J., J.E. Carlson, J.F. Meeder, L.C. Duever, L.H. Gunderson, L. A. Riopelle, T.R. Alexander, R.F. Myers, and D.P. Spangler. 1986. The Big Cypress National Preserve. National Audubon Society Research Report pp 8.1225.

Ebisuzaki, W. 1997. A method to estimate the statistical significance of a correlation when data are serially correlated. Journal of Climatology 10: 2147-2153.

Ewe, S.M.L., L.D.L. Sternberg, and D.E. Busch. 1999. Water-use patterns of woody species in pineland and hammock communities of South Florida. Forest Ecology and Management 118(1-3): 139-148.

Favero, L., E. Mattiuzzo, and D. Franco. 2007. Practical results of a water budget estimation for a constructed wetland. Wetlands 27 (2): 230-239.

Fitterman, D.V, Deszcz-Pan, M., and Stoddard C.E. 1999. Results of time-domain electromagnetic soundings in Everglades National Park, Florida (on CD-ROM), U.S. Geological Survey Open-File Report, pp 99-426.

Fitz, C.H., F.H. Sklar, T. Waring, A.A. Voinov, R. Costanza, and T. Maxwell. 2004. Development and Application of the Everglades Landscape Model. In Spatially explicit landscape simulation models, ed. R. Costanza and A.A. Voinov, 143-171. Berlin: Springer.

Fourqurean, J. 1999. Florida Bay: A history of recent ecological changes. Estuaries and Coasts 22(2): 345-357.

German, E.R. 2000. Regional Evaluation of Evapotranspiration in the Everglades. Water Resources Investigations Report no. 4217, United States Geological Survey, Reston, VA, USA.

Goes, B.J.M. 1999. Estimate of shallow groundwater recharge in the Hadejika-Nguru wetlands, semi-arid northeastern Nigeria. Hydrogeology Journal 7(3): 294-304.

Harvey, J.W., and P.V. McCormick. 2009. Groundwater's significance to changing hydrology, water chemistry, and biological communities of a floodplain ecosystem, Everglades, South Florida, USA. Hydrogeology Journal 17: 185-201.

Hatton, T.J., and R.A. Vertessy. 1990. Transpiration of plantation pinus radiata estimated by the heat pulse method and the Bowen ratio. Hydrological Processes 4(3): 289-298.

Huebner, R.S. 2008. Water budget analysis for stormwater treatment area 2, technical publication \#103, South Florida Water Management District, West Palm Beach, FL, USA.

Koerselman, W. 1989. Groundwater and surface water hydrology of a small groundwater-fed fen. Wetland Ecology and Management 1 (1): $31-43$.

Koerselmann, W., and B. Beltman. 1988. Evapotranspiration from fens in relation to Penman's potential free water evaporation and pan evaporation. Aquatic Botany 31(3-4): 307-320.

Kostner, B. 2001. Evaporation and transpiration from forests in Central Europe: Relevance of patch-level studies for spatial scaling. Meteorology and Atmospheric Physics 76: 69-82.

LaBaugh, J.W. 1986. Wetland system studies from a hydrologic perspective. Water Resources Bulletin 22: 1-10. 
Levesque, V.A. 2004. Water Flow and Nutrient Flux from Five Estuarine Rivers along the southwest coast of Everglades National Park, Florida, 1997-2001. US Geological Survey Scientific Investigations Report 2004-5142. Reston VA, USA. $24 \mathrm{pp}$.

Light, S.S., and J.W. Dineen. 1994. Water control in the everglades: A historical perspective. In Everglades: The ecosystem and its restoration, ed. S.M. Davis and J.C. Ogden, 47-83. Delray Beach: St. Lucie Press.

Lott, R.B., and R.J. Hunt. 2001. Estimating evapotranspiration in natural and constructed wetlands. Wetlands 21(4): 621648.

McCarthy, T.S. 2006. Groundwater in the wetlands of the Okavango Delta, Botswana, and its contribution to the structure and function of the ecosystem. Journal of Hydrology 320(3-4): 264-282.

Mitsch, W.J., and J.G. Gosselink. 1993. Wetlands, 2nd ed, 699. New York: Van Nostrand Reinhold.

Mitsch, W.J., A. Nahlik, P. Wolski, B. Bernal, L. Zhang, and L. Ramberg. 2010. Tropical wetlands: seasonal hydrologic pulsing, carbon sequestration and methane emissions. Wetland Ecology and Management 18(5): 573-586.

Nemeth, M.S., W.M.Wilcox, and H.M. Solo-Gabriele. 2000. Evaluation of the Use of Reach Transmissivity to Quantify Leakage beneath Levee 31N, Miami-Dade County, Florida. USGS Technical Report 00-4066, Tallahassee, FL, USA. pp 53.

Nungesser, M.K., and M.J. Chimney. 2006. A hydrological assessment of the Everglades Nutrient Removal Project, a subtropical constructed wetland in South Florida, USA. Ecological Engineering 4(1): 331344.

Nuttle, W. 1995. Dynamics of groundwater, surface water and salinity related to the mangrove/marsh ecotone. Interannual and multiyear variation in the hydrology of Shark Slough. Report prepared for Global Climate Change Research Program: South Florida Biogeographical Region.

Olmsted, I.C., and L.L. Loope. 1984. Plant communities of Everglades National Park. In Environments of south Florida: Present and past II. Coral gables, ed. P.J. Gleason, 167-184. Miami: Miami Geological Society.

Price, R.M., P.K. Swart, and J.W. Fourqurean. 2006. Coastal groundwater discharge-an additional source of phosphorus for the oligotrophic wetlands of the Everglades. Hydrobiologia 569: 23-36. doi:10.1007/s10750-006-0120-5.

Priestley, C.H.B., and R.J. Taylor. 1972. On the assessment of surface heat flux and evaporation using large-scale parameters. Monthly Weather Review 100(2): 81-92.

Ramberg, L., P. Wolski, and M. Krah. 2006. Water balance and infiltration in a seasonal floodplain in the Okavango delta, Botswana. Wetlands 26(3): 677-690.

Rawson, H.M., J.E. Begg, and R.G. Woodward. 1977. The effect of atmospheric humidity on photosynthesis, transpiration and water use efficiency of leaves of several plant species. Planta 134(1): 5-10.

Rehage, J., and J. Trexler. 2006. Assessing the net effect of anthropogenic disturbance on aquatic communities in wetlands: Community structure relative to distance from canals. Hydrobiologia 569(1): 359-373.

Riscassi, A., and R. Schaffranek R. 2004. Flow velocity, Water Temperature and Conductivity in Shark River Slough, Everglades National Park, Florida: June 2002-July 2003. USGS Open File Report 04-1233, USGS, Reston, VA, USA. $64 \mathrm{pp}$.

Rodriguez-Rodriguez, M., F. Moral, and J. Benavente. 2007. Hydromorphological characteristics and hydrogeological functioning of a wetland system: A case study in southern Spain. Environmental Geology 52: 1375-1386.
Ropelewski, C.F., and M.S. Halpert. 1986. North-American precipitation and temperature pattern associated with the El Nino Southern Oscillation (ENSO). Monthly Weather Review 114 (12): 2352-2362.

Ross, M.S., E.E. Gaiser, J.F. Meeder, and M.T. Lewin. 2001. Multi-taxon analysis of the "white zone", a common ecotonal feature of South Florida coastal wetlands. In The Everglades, Florida Bay and coral reefs of the Florida keys: An ecosystem sourcebook, ed. J.W. Porter and K.G. Porter, 205-238. Boca Raton: CRC.

Ruhl, C., and M. Simpson. 2005. Computation of Discharge Using the Index-Velocity method in tidally affected areas. USGS Scientific Investigations Report 2005-5004. USGS.

Rushton, B. 1996. Hydrological Budget for a freshwater marsh in Florida. Water Resources Bulletin Vol 32 No 1. American Water Resources Association.

Saha, A.K., L.S. Sternberg, and R. Miralles-Wilhelm. 2009. Linking water sources with foliar nutrient status in upland plant communities in the Everglades National Park, USA. Ecohydrology 1(2): 42-54.

Saha, A.K., S. Saha, J. Sadle, M.S. Ross, J. Jiang, R.M. Price, L.S.L. Sternberg, and K. Wendelburger. 2011. Sea level rise and south Florida coastal forests. Journal of Climatic Change 107(1-2): 81-108.

Shoemaker, W.B., S. Huddleston, C.L. Boudreau, and A.M. O'Reilly. 2008. Sensitivity of wetland saturated hydraulic heads and water budgets to evapotranspiration. Wetlands 28(4): 1040-1047.

Shuttleworth, J. 1992. Evaporation. In Handbook of hydrology, ed. D. Maidment, 4.1-4.53. New York: McGraw-Hill.

Simard, M., K. Zhang, V.H. Rivera-Monroy, M.S. Ross, P.L. Ruiz, E. Castenada-Moya, R.W. Twilley, and E. Rodriguez. 2006. Mapping height and biomass of mangrove forests in Everglades national park with SRTM elevation data. Photogrammetric Engineering and Remote Sensing 72(3): 299311.

Skinner, C., F. Bloetscher, and C.S. Pathak. 2009. Comparison of NEXRAD and rain gauge precipitation measurements in South Florida. Journal of Hydrologic Engineering 14(3): 248-261.

Smith III, T.J., J.H. Hudson, M.R. Robblee, G.V.N. Powell, and P.J. Isdale. 1989. Freshwater flow from the Everglades to Florida bay: A historical reconstruction based on fluorescent banding in the coral Solenastrea Bournoni. Bulletin of Marine Science 44(1): 274-282.

Sophocleous, M. 2002. Interactions between groundwater and surface water: The state of the science. Hydrogeology Journal 10: $52-76$.

Sternberg, L.D.L., S.Y. Teh, S.M.L. Ewe, F.M. Wilhelm, and D.L. DeAngelis. 2007. Competition between hardwood hammocks and mangroves. Ecosystems 10: 648-660.

Suleiman, A.A., and G. Hoogenboom. 2007. Comparison of PriestleyTaylor and FAO-56 Penman-Monteith for daily reference evapotranspiration estimation in Georgia. Journal of Irrigation and Drainage Engineering 133(2): 175.

Sullivan, P.L., R.M. Price, M.S. Ross, L.J. Scinto, S.L. Stoffella, E. Cline, T.W. Drechel, and F.H. Sklar. 2010. Hydrologic processes of tree islands in the Everglades: Tracking the effects of tree establishment and growth. Hydrogeology Journal. doi:10.1007/ s10040-010-0691-0.

Sutula, M., J.W. Day, J. Cable, and D. Rudnick. 2001. Hydrological and nutrient budgets of freshwater and estuarine wetlands of Taylor Slough in Southern Everglades, Florida (U.S.A.). Biogeochemistry 56: 287-310.

Tardieu, F., and T. Simonneau. 1998. Variability among species of stomatal control under fluctuating soil water status and evaporative demand: Modelling isohydric and anisohydric behaviours. Journal of Experimental Botany 49: 419-432. 
Thiessen, A.H. 1911. Precipitation averages for large areas. Monthly Weather Review 39: 1082-1089.

Turc, L. 1961. Valuation Des Besoins En Eau D'Irrigation, vapotranspiration Potentielle: Formule Climatique Simplifiée Et Mise. Journal Annual Agronomie 12(1): 13-49.

Villalobos R. 2010. Water table and nutrient dynamics in neotropical savannas and wetland ecosystems. Ph.D. dissertation, University of Miami.

Wang, X., L.O. Sternberg, M.S. Ross, and V.C. Engel. 2010. Linking water use and nutrient accumulation in tree island upland hammock plant communities in the Everglades National Park, USA. Biogeochemistry. doi:10.1007/s10533-0109492-8.
Wanless, H.R., R.W. Parkinson, and L.P. Tedesco. 1994. Sea level control on stability of Everglades wetlands, 199-223. Boca Raton: St. Lucie Press.

Yoder, R.E., L.O. Odhiambo, and W.C. Wright. 2005. Evaluation of methods for estimating daily reference crop evapotranspiration at a site in the humid Southeast United states. Applied Engineering in Agriculture 21(2): 197-202.

Zapata-Rios, J. 2009. Groundwater/surface water interactions in Taylor Slough -Everglades National Park. Masters thesis in Geosciences, Florida International University, Miami, FL, USA. 98 pp.

Zhang, L., and W. Mitsch. 2005. Modelling hydrological processes in created freshwater wetlands: An integrated system approach. Environmental Modeling and Software 20: 935-946. 